\title{
THE CICADA GENUS Semia Matsumura, 1917 (Hemiptera: Cicadidae) FROM VIETNAM, WITH NEW RECORDS AND A KEY TO SPECIES
}

\author{
Pham Hong Thai ${ }^{1 *}$, Jérôme Constant ${ }^{2}$ \\ ${ }^{1}$ Vietnam National Museum of Nature, VAST, *phamthai@vnmn.vast.vn \\ ${ }^{2}$ Royal Belgian Institute of Natural Sciences, Belgium
}

\begin{abstract}
The genus Semia Matsumura that is from East Asia. According to Lee \& Hill, 2010, this genus belongs to subtribe Psithyristriina within the tribe Cicadini. There are six species S. watanabei (Matsumura), S. klapperichi Jacobi, S. lachna Lei \& Chou, S. majuscula Distant, $S$. spinosa Pham, Hayashi \& Yang, and S. gialaiensis Pham \& Constant. A revised description of the cicada species Semia watanabei (Matsumura, 1907) is provided. A key to the four Vietnamese Semia species: S. majuscula (Distant), S. watanabei (Matsumura), S. spinosa Pham, Hayashi \& Yang, and S. gialaiensis Pham \& Constant is provided. Synonymic lists and new locality records for the four species of Semia from Vietnam are provided.
\end{abstract}

Keywords: Auchenorrhyncha, Cicada, Semia, morphology, new record, Vietnam.

\section{INTRODUCTION}

The cicada genus Semia Matsumura, 1917, containing six species: S. watanabei (Matsumura, 1907), originally known from Taiwan [11], S. klapperichi Jacobi, 1944 from Fukien Province, China, S. lachna Lei \& Chou, from Hainan Province, China, S. majuscula Distant from Vietnam and Laos, S. spinosa Pham, Hayashi \& Yang, 2012, from Vietnam, and S. gialaiensis Pham \& Constant, 2013 from Vietnam [2, 24, 25].

Pomponia lachna Lei \& Chou and Terpnosia majuscula (Distant) were transferred to Semia [14]. Recently, Pham et al. (2012) [25] described S. spinosa from south Vietnam and Pham \& Constant (2013) [24] described $S$. gialaiensis from Gia Lai province, Tay Nguyen area, Vietnam.

Prior to this work, three species of Semia were known to occur in Vietnam. A fourth species is recorded herein from Vietnam, previously known from Taiwan. A key to all 4 species of Semia from Vietnam is provided.

\section{MATERIALS AND METHODS}

A male of the species Semia watanabei, was collected from the Xuan Lien nature reserve, Thuong Xuan district, Thanh Hoa province in north Vietnam. Material studied for this paper is deposited in the Vietnam National Museum of Nature, Hanoi, Vietnam.

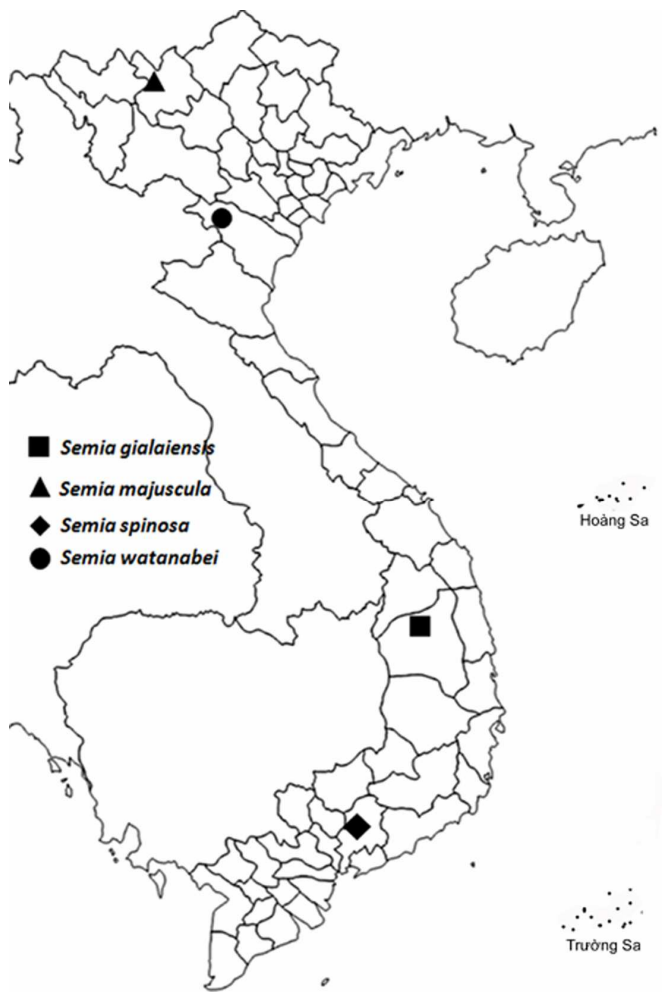

Figure 1. Distribution of the Semia species in Vietnam

Nomenclature for family, subfamily and tribal classification follows Lee \& Hill (2010) [12]. Morphological terminology follows Moulds (2012) [22]. The male genitalia of the Vietnam record of $S$. watanabei was examined 
and photographed using a dissecting microscope (Leica EZ4 HD) (fig. 3). A distribution map produced by the software CFF 2.0 [1] for Semia species from Vietnam (Fig. 1), and photos of habitus for $S$. watanabei are provided (fig. 2).

Abbreviations used in this paper are as follows: VNMN. Vietnam National Museum of Nature, Hanoi, Vietnam; NP. National Park.

\section{RESULTS AND DISCUSSION}

\section{Genus Semia Matsumura, 1917}

Semia Matsumura, 1917: 195. Type species: Leptopsaltria watanabei Matsumura, 1907 (Formosa).

Diagnosis. Head nearly as wide as or slightly narrower than base of mesonotum; inner area of pronotum generally concolorous to outer dilatation; male abdomen cylindrical, much longer than distance from head to cruciform elevation and slightly widest across 4th abdominal segment and wider than base of mesonotum; male tymbal cover very small and semicircular, mostly exposing tymbal in dorsal view; male 8th abdominal tergum mostly covered with white powder; ovipositor not protruding beyond abdominal segment 9; male operculum scale-like, roundish, and not extending beyond 2nd abdominal sternum; wings hyaline; 6 th apical cell of forewing about as long as or longer than twice of 5 th apical cell in median length [16].

\section{Key to the species of the genus Semia from Vietnam}

1. Hind wing without infuscation along hind margins of apical cells

Hind wing with continuous infuscation along hind margins of apical cells 1-6...S. majuscula

2. Abdomen with central, longitudinal broad brown streak; uncus lobes triangular and divergent, uncus lobe with two spines (fig. 4F) S. spinosa

Abdomen without central, longitudinal broad brown streak; uncus lobe without two spines.

3. Uncus lobe with one projection protruding from below the uncus and parallel with uncus lobe (fig. 4G), body length 32-34 mm. S. gialaiensis

Uncus lobe without one large projection protruding from below the uncus and parallel with uncus lobe (fig. 4E), body length approximately $38 \mathrm{~mm}$. S. watanabei

\section{Semia watanabei (Matsumura, 1907)}

Leptopsaltria watanabei Matsumura, 1907: 96 [TL: Hoppo, Formosa]; Schmidt, 1932: 123.

Pomponia watanabei: Matsumura, 1913: 78.

Semia watanabei: Matsumura, 1917: 196; Kato, 1925a: 32; Kato, 1926b: 175; Kato, 1927a: 33; Kato, 1930: 53,67; Kato, 1931: 221; Kato, 1932: 295; Schmidt, 1932: 125; Kato, 1933, pIs. 28-29; Hirayama, 1937: 184; Kato, 1938a: 13; Kato, 1956: 116, 133,187; Hayashi, 1979: 260; Duffels and van der Laan, 1985: 112.

Material examined: $1 \hat{\sigma}$ : Xuan Lien nature reserve, Thanh Hoa, 16-23.IV.2012, coll. Hoang $\mathrm{Vu}$ Tru (VNMN).

Redescription: Head: head pale yellowishbrown with following markings: broad median longitudinal band on frons and supra-antennal plate, dark brown; postclypeus dorsally with two oblique oval dark brown patches, in facial view upper half with transverse brown bands, lower half blackish brown; lower half of anteclypeus blackish brown, area between eye and antenna on gena, lorum and apex of rostrum, dark brown. Head including eyes as wide as mesonotum at base; rostrum reaching posterior coxae.

Thorax (figs 2A, 2B): pale yellowish-green, longitudinal broad band on pronotum narrowed centrally, longitudinal broad band on mesonotum, spot between submedian and lateral sigillae, scutal depression, two spots on lateral margin of mesonotum, central area of cruciform elevation, second anepisternum, anepimeron and katepisternum, dark brown. Pronotal collar with a small dentate projection. 
A

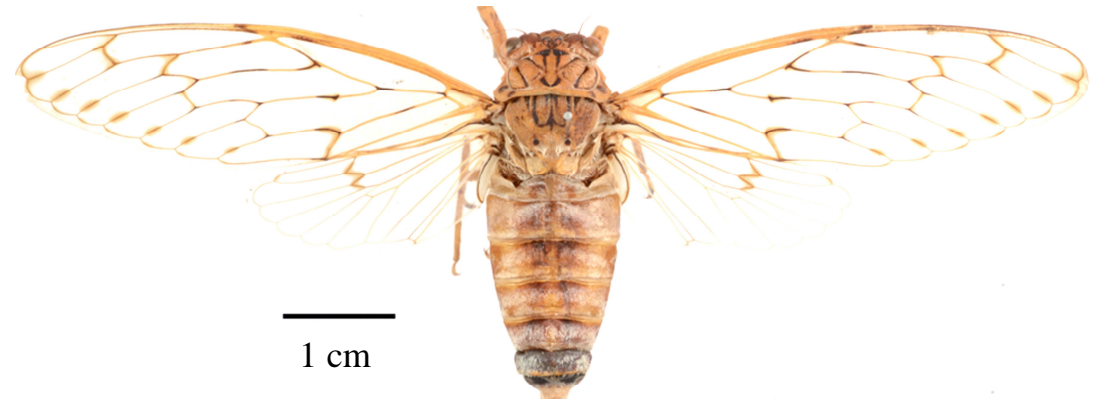

$\mathbf{B}$

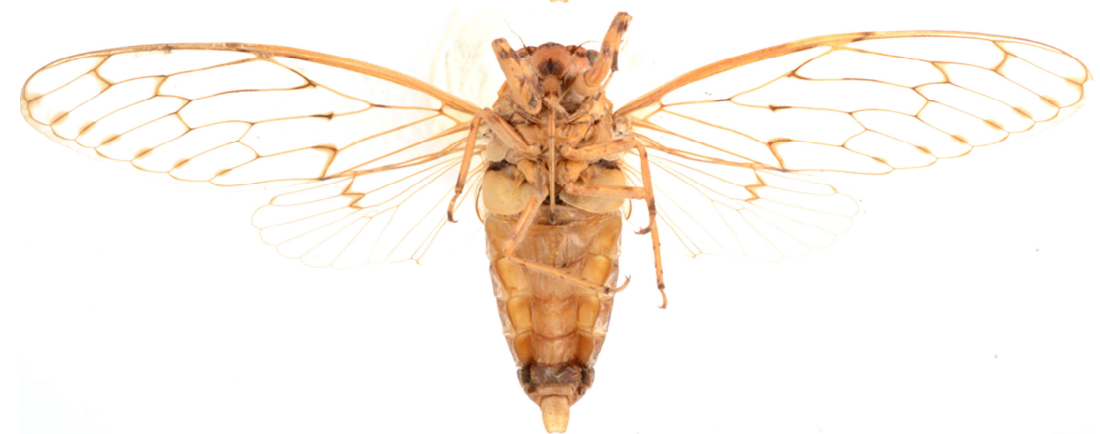

Figure 2. Semia watanabei (Matsumura, 1907): A. dorsal view of male; B. ventral view of male.

A
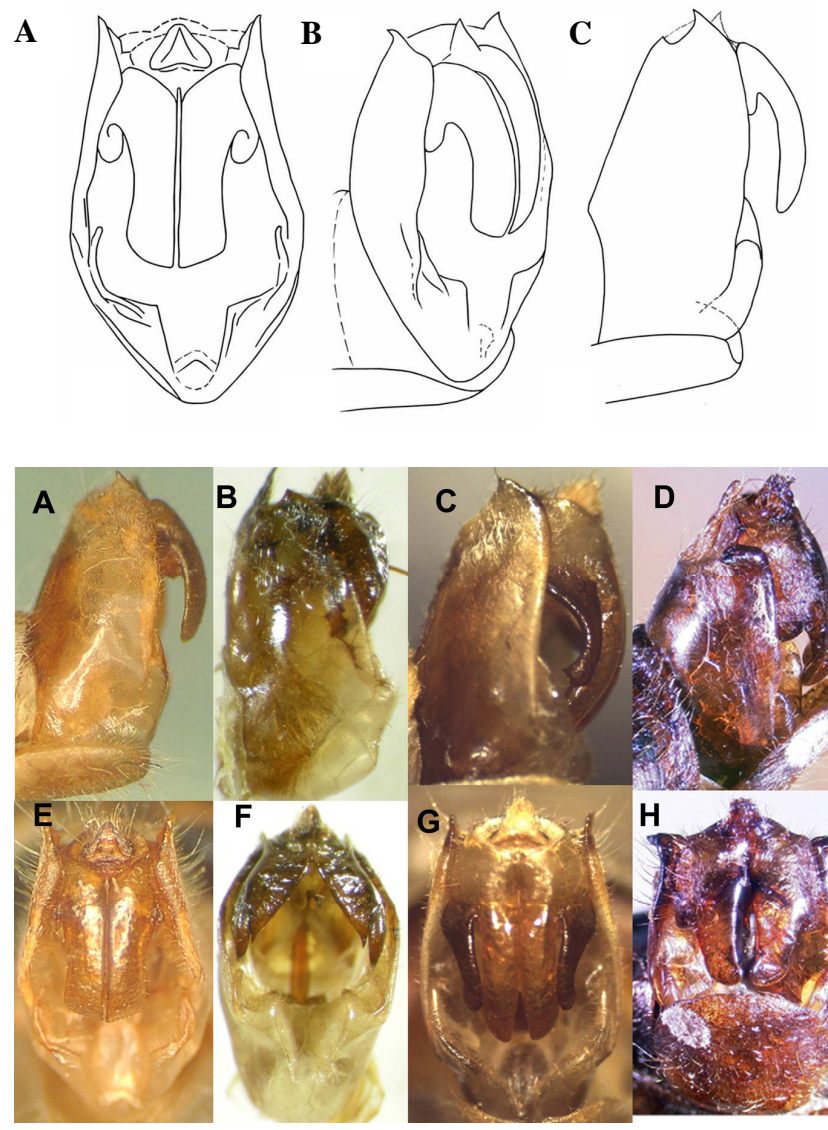

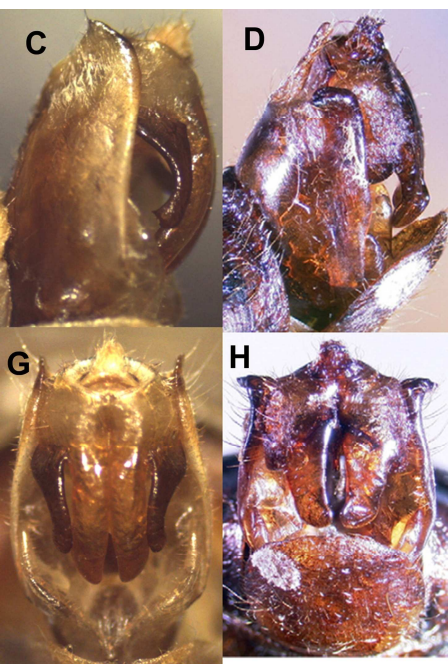

Figure 3. Semia watanabei (Matsumura, 1907): A. male genitalia in ventral view; B. male genitalia in lateroventral view; C. male genitalia in lateral view.

Figure 4. Male genitalia of Semia species in lateral view. S. watanabei: A; S. spinosa: B (after Pham et al., 2012); S. gialaiensis (after Pham \& Constant, 2013): C; S. majuscula: D (after Lee, 2012a) and in ventral view. S. watanabei: E; S. spinosa: F (after Pham et al., 2012); $S$. gialaiensis (after Pham \& Constant, 2013): G; S. majuscula: H (after Lee, 2012a). 
Wings (fig. 2A): fore and hind wings hyaline, with veins brown or fuscous, and costal margin tawny; fore wings slightly tinged and spotted with infuscations on most veins.

Legs (fig. 2B): pale yellow with markings as follows: fore leg with femur, tibia, metatarsus and pretarsus blackish brown, primary spine of femur dark brown, secondary spine dark brown; mid leg with coxa and femur pale yellow, tibia pale brown, apex of femur black, apex and base of tibia black, metatarsus and pretarsus dark brown, mesotarsus pale yellow; hind leg, with femur pale yellow, apex of femur dark brown, tibia pale brown, base of tibia dark brown, tibial spur, tibial comb, and thumb of tibial comb dark brown.

Abdomen (fig. 2B): pale greenish brown in dorsal view, with a longitudinal broad dark brown streak, tergites 3-7 with their lateral margins edged pale brown (fig. 2A); pale brown in ventral view, anterior margin of sternites III VI and sternites VII and VIII dark brown; epipleurites 3-6 lighter than sternites (fig. 2B). abdomen brownish ochreous with few markings; male 6th and 7th abdominal segments darker than other segments; male 8th tergum covered with thick white pollinosity.

Operculum (fig. 2B): pale yellow-green, short, transverse, and not reaching beyond anterior margin of sternite II, with a triangular blackish marking at anterolateral part.

Male genitalia (figs 3A, B): Pygofer oblong in ventral view, with an acute triangular caudal beak; uncus with a pair of long lobes, which are substantially, roundly curved inward; Anal styles and anal tube dark brown. Aedeagus very slender.

Measurements in $\mathrm{mm}:\left(1{ }^{\Uparrow}\right)$ : body length: 33.4; fore wing length: 42.1; fore wing width: 12.1; head width: 9.0; pronotum width: 10.6.

Distribution: Taiwan, Vietnam (New Country Record).

\section{Semia gialaiensis Pham \& Constant, 2013}

Semia gialaiensis: Pham \& Constant, 2013: 496.

Material examined : $\hat{\sigma}$ (holotype):
Vietnam, Kon Ka Kinh NP, Dak Roong, Kbang, Gia Lai province, 22.II.2012, light trap, $14^{\circ} 25^{\prime} 41.3^{\prime}$ 'N $108^{\circ} 21^{\prime} 32.9^{\prime \prime} \mathrm{E}, 1230 \mathrm{~m}$, coll. Hoang Vu Tru (VNMN); Paratypes: 5 $\delta^{\lambda}$ (paratypes): Vietnam: Kon Ka Kinh NP, Dak Roong, Kbang, Gia Lai province, 22.II.2012, $14^{\circ} 25^{\prime} 41.3^{\prime}$ 'N, 108 $21^{\prime} 32.9^{\prime \prime} \mathrm{E}, 1230 \mathrm{~m}$, coll. Hoang Vu Tru (VNMN); $1 \delta^{\text {}}$ : same locality, 18.III.2012, light trap, $14^{\circ} 25^{\prime} 30.5^{\prime}{ }^{\prime} \mathrm{N}$, 108²4'06.4''E, 1060 m, coll. Tran Thieu Du (VNMN); $1 \delta^{\Uparrow}$ : Kon Ka Kinh NP, A Yun, Mang Yang, Gia Lai province, 29.II.2012, light trap, $14^{\circ} 12^{\prime} 11.3^{\prime \prime} \mathrm{N}, 108^{\circ} 18^{\prime} 49.0^{\prime \prime} \mathrm{E}, 880 \mathrm{~m}$, coll. Hoang Vu Tru (VNMN).

\section{Distribution: Vietnam (Gia Lai).}

Remarks: The new species differs from S. klapperichi in the infuscations on the hind wing which lacks spots along ambient veins while S. klapperichi has spots along ambient vein. S. gialaiensis sp.nov. is distinguishable from $S$. spinosa and $S$. watanabei by the body size, which is shorter than $34 \mathrm{~mm}$ in S. gialaiensis, $38 \mathrm{~mm}$ in $S$. watanabei, and shorter than $30 \mathrm{~mm}$ in $S$. spinosa. The new species also differs from $S$. majuscula and $S$. lachna in the structure of the uncus, which has one large projection protruding from below the uncus and running parallel with the uncus lobe in the new species, uncus lobe tapering to subapex and expanded roundedly at apex in $S$. majuscula, and uncus lobe with much widened apex in S. lachna [24].

\section{Semia majuscula (Distant, 1917)}

Terpnosia majuscula Distant, 1917b: 319, 323 [TL: Laos; Chapa]; Metcalf, 1963a: 436; Lee, 2008a: 9; Pham \& Yang, 2009: 14.

Material examined: No specimen was examined.

Diagnosis: Anterolateral margin of pronotum very weakly ampliated. Forewing crossvein $r$ nearly parallel to outer magin of forewing. Forewing ulnar cell 1 not longer than ulnar cell 2. Forewingwith infuscations on crossveins $\mathrm{r}, \mathrm{r}-\mathrm{m}, \mathrm{m}$, and $\mathrm{m}-\mathrm{cu}$ and bases of veins RA2, RP, M1-4, and CuA1, vein $\mathrm{CuA2}$, apical area of cubitus posterior+anal vein 1 $(\mathrm{CuP}+1 \mathrm{~A})$, part of vein $\mathrm{M}$ between $\mathrm{rc}$ and $\mathrm{u} 2$, 
and vein parts around nodal line intersection. Roundish infuscation present on each hind margin of veins RA2, RP, M1-4, and CuA1. Hind wing with continuous infuscation along hind margins of apical cells 1-6. Male abdominal tergite 8 without white pollinosity. Timbal cover rudimentary, wider than long. Uncal lobe tapering to subapex but bulbous (expanded roundedly) at apex, being slightly twisted longitudinally at apex [14].

Distribution: Vietnam ( $\mathrm{Sa} \mathrm{Pa}$, Lao Cai); Laos.

\section{Semia spinosa Pham, Hayashi \& Yang, 2012}

Semia spinosa: Pham, Hayashi \& Yang, 2012: 33 .

Material examined: $\hat{\sigma}$ (holotype): VIETNAM [VC.Ho.0650, Phu Ly, Ma Da-Vinh Cuu NR, Dong Nai Province, 4.VIII.2008, light trap, $11^{\circ} 24^{\prime} 42.4^{\prime \prime} \mathrm{N}, 107^{\circ} 06^{\prime} 19.5^{\prime \prime} \mathrm{E}, 100-150 \mathrm{~m}$, coll. Hoang $\mathrm{Vu}$ Tru] (VNMN)., $2 \hat{\jmath}$ (paratypes): VIETNAM [ VC.Ho.0626, 0631, Phu Ly, Ma Da-Vinh Cuu NR, Dong Nai Province, 31.VII.2008, 100-150 m, coll. Hoang Vu Tru] (VNMN).

\section{Distribution: Vietnam (Dong Nai).}

Remarks: $S$. spinosa is distinguishable from $S$. watanabei and $S$. klapperichi by the body size, which is shorter than $30 \mathrm{~mm}$ (in male) in $S$. spinosa and longer than $35 \mathrm{~mm}$ (in male) in S. watanabei and S. klapperichi, and from $S$. klapperichi it differs in the infuscations on the hind wings which lack spots along the ambient veins present in $S$. klapperichi. The new species also differs in the structure of the uncus which has the lobes strongly divergent with acute apical spines [25].

Acknowledgments: We thank Mr. Hoang $\mathrm{Vu}$ Tru (Institute of Ecology and Biological Resources, VAST) for assistance with field work sharing of specimens and data. We thank Dr. Steven Lingafelter (USDA, Smithsonian Institution, National Museum of Natural History, Washington, DC, U.S.A) for his critical reading and valuable comments in improving the contents of the paper. The present study was supported by National Foundation for Science and Technology Development (NAFOSTED106.12-2012.63), Vietnam, the International Foundation for Science (IFS-No D/5181-1), Sweden, and the Nagao Natural Environment Foundation, Japan. We also thank Dr. MarieLucie Susini and Dr. Patrick Grootaert (Royal Belgian Institute of Natural Sciences), for the grant support to the first author. The grant issued by the capacity building Programme of the Belgian Global Taxonomic Initiative National Focal Point that runs with financial support from the Belgian Directorate-General for Development Cooperation. The first author thank to IDEA WILD has donated equipment for this study.

\section{REFERENCES}

1. Barbier Y., Rasmont P., 2000. Carto FaunaFlora 2.0. Guide d'utilisation. Université de Mons Hainaut, Mons, Belgique, 59 pp.

2. Chou I., Lei Z., Li L., Lu X., Yao W., 1997. The cicadidae of China (Homoptera: Cicadoidea). Ilustrataj Insect-faunoj, 2. Tianze Eldoneio, Hong Kong. 10+380+5 pp., 4+16 pls. (in Chinese with English summary).

3. Distant W. L., 1912. Homoptera, Fam. Cicadidae, Subfam. Cicadinae. Genera insectorum, 142: 1-64. pls. 1-7.

4. Distant W. L., 1917. The Homoptera of Indo-China. Ann. Mag. Nat. Hist., 8(20): 319-325.

5. Duffels J. P., Van der Laan P. A., 1985. Catalogue of the Cicadoidea (Homoptera, Auchenorhyncha) 1956-1980., 34. Dr. W. Junk Publishers, Dordrecht, xiv+414 pp.

6. Hayashi M., 1979. A list of Taiwanese Cicadidae collected by Prof. K. Kojima and Mr. S. Nakamura (Homoptera). Rostria, 30: 259-262 (in Japanese with English summary).

7. Jacobi A., 1944. Die Zikadenfauna der Provinz Fukien in Sudchina und ihre tiergeographischen Beziehungen. Mitteilungen der münchener entomologischen Gesellschaft, 34: 5-66.

8. Kato M., 1925. Japanese Cicadidae, with 
descriptions of new species. Trans. Nat. Hist. Soc. Formosa, 15: 1-46 1 pl. (in Japanese).

9. Kato M., 1932. Monograph of Cicadidae. Sanseido, Tokyo. 450 pp., 32 pls. (in Japanese).

10. Kato M., 1933. Three colour illustrated insects of Japan, fasc. 3 (Homoptera). Kôseikaku, Tokyo. 9(+50)+11 pp., 50 pls. (In Japanese).

11. Lee Y. J., Hayashi M., 2003. Taxonomic review of Cicadidae (Hemiptera, Auchenorrhyncha) from Taiwan, part 2 . Dundubiini (a part of Cicadina) with two new species. Insecta Koreana, 20: 359-392.

12. Lee Y. J., Hill K. B. R., 2010. Systematic revision of the genus Psithyristria Stal (Hemiptera: Cicadidae) with seven new species and a molecular phylogeny of the genus and higher taxa. Systematic Entomology, 35: 277-305.

13. Lee Y. J., 2008. A checklist of Cicadidae (Insecta: Hemiptera) from Vietnam, with some taxonomic remarks. Zootaxa, 1787, 127.

14. Lee Y. J., 2012a. A review of the cicada genus Semia Matsumura (Hemiptera: Cicadidae: Cicadini). Journal of AsiaPacific Entomology, 15: 427-430.

15. Lee Y.J., 2012b. Resurrection of the genus Yezoterpnosia Matsumura (Hemiptera: Cicadidae: Cicadini) based on a new definition of the genus Terpnosia Distant. Journal of Asia-Pacific Entomology, 5: 255258.

16. Lee Y. J., Hayashi M., 2003. Taxonomic review of Cicadidae (Hemiptera, Auchenorrhyncha) from Taiwan, part 2 . Dundubiini (a part of Cicadina) with two new species. Ins. Koreana, 20: 359-392.
17. Matsumura S., 1907. Die Cicadinen Japans. Annotationes Zoologicae Japonenses, 6: 83116.

18. Matsumura S., 1913. Thousand insects of Japan, additamenta 1: 1-184, pls. 1-15. (in Japanese).

19. Matsumura S., 1917. A list of the Japanese and Formosan Cicadidae, with description of new species and genera. Transactions of the Sapporo Natural History Society, 6: 186-212.

20. Metcalf Z. P., 1963. General catalogue of the Homoptera, fascicle VIII, Cicadoidea, part 1. Cicadidae. section I. Tibiceninae. North Carolina State College, Raleigh, pp. $1-585$.

21. Moulds M. S., 2005. An appraisal of the higher classification of cicadas (Hemiptera: Cicadoidea) with special reference to the Australian fauna. Records of the Australian Museum, 57: 375-446.

22. Moulds M.S., 2012. A review of the genera of Australian cicadas (Hemiptera: Cicadoidea). Zootaxa, 3287: 1-262.

23. Pham H. T., Yang J. T., 2009. A contribution to the Cicadidae fauna of Vietnam (Hemiptera: Auchenorrhyncha), with one new species and twenty new records. Zootaxa, 2249: 1-19.

24. Pham H. T., Constant J., 2013. A new species of the cicada genus Semia Matsumura, 1917 (Hemiptera: Cicadidae) from Vietnam, with a key to the species of the genus. Zootaxa, 3709(5): 494-500.

25. Pham H. T., Hayashi M., Yang J. T., 2012. First record of the cicada genus Semia Matsumura (Hemiptera, Cicadidae) from Vietnam, with description of one new species and a key to species. Zookeys, 174: 31-40. 


\title{
GIỐNG Semia Matsumura, 1917 (Hemiptera: Cicadidae) VỚI GHI NHậN MỚI MỘT LOÂI CHO KHU HỆ CỦA VIỆT NAM
}

\author{
Phạm Hồng Thái ${ }^{1}$, Jérôme Constant ${ }^{2}$ \\ ${ }^{1}$ Bảo tàng Thiên nhiên Việt Nam, Viện Hàn lâm KH \& CN Việt Nam \\ ${ }^{2}$ Viện Khoa học tự nhiên Hoàng gia Bỉ, Vương quốc Bỉ
}

\section{TÓM TÁT}

Ghi nhận mới và mô tả loài ve sầu Semia watanabei (Matsumura, 1907) cho khu hệ côn trùng Việt Nam thuộc giống Semia Matsumura. Mẫu vật của loài này thu được ở khu bảo tồn thiên nhiên Xuân Liên, tỉnh Thanh Hóa. Hình ảnh mẫu vật cá thể con trưởng thành, cấu tạo bộ phận sinh dục của con đực và bản đồ phân bố của chúng được cung cấp. Khóa định loại của các loài thuộc giống Semia dựa vào cá thể đực con trưởng thành ghi nhận có mặt ở Việt Nam được trình bày. Loài mới này được phân biệt với tất cả các loài còn lại của nhóm loài này bởi cấu trúc của bộ phận sinh dục con đực trưởng thành. Bộ phận sinh dục con đực nhìn từ phía bụng hình thuôn dạng chữ nhật, với lớp lông tơ dài ở mép bên; thùy gốc của bộ phận sinh dục con đực hình chữ $\mathrm{S}$ với đỉnh nhô lên rõ rệt, thùy bên của bộ phận sinh dục con đực nhìn từ phía bụng với mép ở đỉnh thẳng và rộng; một đường hẹp lượn tròn hơi cong ở phía trong; uncus phân nhánh, thùy uncus kéo dài; dorsal beak sắc nhọn, màu nâu; anal styles và anal tube màu nâu tối.

Tù khóa: Semia watanabei, ghi nhận mới, hình thái học, ve sầu và rầy, Việt Nam.

Ngày nhận bài: 15-6-2013 